\title{
Evaluation of Thermal and Physical Properties of Magnesium Nitride Powder: Impact of Biofield Energy Treatment
}

\author{
Mahendra Kumar Trivedi ${ }^{1}$, Rama Mohan Tallapragada', Alice Branton ${ }^{1}$, Dahryn Trivedi', Gopal Nayak ${ }^{1}$, Omprakash Latiyal ${ }^{2}$ and Snehasis \\ Jana $^{2 *}$
}

${ }^{1}$ Trivedi Global Inc., 10624 S Eastern Avenue Suite A-969, Henderson, NV 89052, USA

${ }^{2}$ Trivedi Science Research Laboratory Pvt. Ltd., Hall-A, Chinar Mega Mall, Chinar Fortune City, Hoshangabad Rd., Bhopal-462026, Madhya Pradesh, India

\begin{abstract}
Magnesium nitride $\left(\mathrm{Mg}_{3} \mathrm{~N}_{2}\right)$ has gained extensive attention due to its catalytic and optoelectronic properties. The present investigation was aimed to evaluate the effect of biofield energy treatment on physical and thermal properties of $\mathrm{Mg}_{3} \mathrm{~N}_{2}$ powder. The $\mathrm{Mg}_{3} \mathrm{~N}_{2}$ powder was divided into two parts i.e. control and treated. The control part was remained as untreated and the treated part was subjected to the Mr. Trivedi's biofield energy treatment. Subsequently, the control and treated $\mathrm{Mg}_{3} \mathrm{~N}_{2}$ samples were characterized using differential scanning calorimetry (DSC), thermogravimetric analysis (TGA), and X-ray diffraction (XRD). The DSC results showed the specific heat capacity of $2.24 \mathrm{Jg}^{-1} \mathrm{C}^{-1}$ in control, which increased upto $5.55 \mathrm{Jg}^{-10} \mathrm{C}^{-1}$ in treated $\mathrm{Mg}_{3} \mathrm{~N}_{2}$ sample. The TGA data revealed that the onset temperature for the formation of magnesium oxide, possibly due to oxidation of $\mathrm{Mg}_{3} \mathrm{~N}_{2}$ in the presence of air and moisture, was reduced from $421.0^{\circ} \mathrm{C}$ (control) to $391.33^{\circ} \mathrm{C}$ in treated sample. Besides, the XRD data revealed that the lattice parameter and unit cell volume of treated $\mathrm{Mg}_{3} \mathrm{~N}_{2}$ samples were increased by 0.20 and $0.61 \%$ respectively, as compared to the control. The shifting of all peaks toward lower Bragg angle was observed in treated sample as compared to the control. The XRD diffractogram also showed that the relative intensities of all peaks were altered in treated sample as compared to control. In addition, the density of treated $\mathrm{Mg}_{3} \mathrm{~N}_{2}$ was reduced by $0.60 \%$ as compared to control. Furthermore, the crystallite size was significantly increased from $108.05 \mathrm{~nm}$ (control) to $144.04 \mathrm{~nm}$ in treated sample as compared to the control. Altogether data suggest that biofield energy treatment has substantially altered the physical and thermal properties of $\mathrm{Mg}_{3} \mathrm{~N}_{2}$ powder. Thus, the biofield treatment could be applied to modulate the catalytic and optoelectronic properties of $\mathrm{Mg}_{3} \mathrm{~N}_{2}$ for chemical and semiconductor industries.
\end{abstract}

Keywords: Biofield energy treatment; Magnesium nitride powder; $\mathrm{X}$-ray Diffraction; DSC; TGA

\section{Introduction}

Magnesium nitride $\left(\mathrm{Mg}_{3} \mathrm{~N}_{2}\right)$ is well-known for its role as an additive in a range of applications, including fabricating special alloys and ceramics, catalyzing polymer cross-linking reactions etc. [1]. Generally, $\mathrm{Mg}_{3} \mathrm{~N}_{2}$ is applied as catalysts to prepare some metal nitrides or non-metal nitrides, especially cubic boron nitride. It is a convenient source of ammonia in the preparation of primary amides and dihydropyridines [2]. Recently, $\mathrm{Mg}_{3} \mathrm{~N}_{2}$ powder has shown enormous potential for fabricating hydrogen storage materials [3]. In addition, it is also used in the formation of high thermal conductivity ceramics [4]. It has attracted considerable interest in optoelectrical field due to its direct band gap of 1.1 to $2.5 \mathrm{eV}$ [5]. Besides, in catalytic activities of $\mathrm{Mg}_{3} \mathrm{~N}_{2}$, its thermal and physical characteristics play a vital role. Recently, researcher have used various processes to prepare $\mathrm{Mg}_{3} \mathrm{~N}_{2}$ powder with desired physical and thermal properties such as $\mathrm{Mg}$ direct reaction with $\mathrm{NH}_{3}$ [1], low pressure chemical vapor deposition method [6], and electrochemical process [7] etc. All these process required either expensive equipment or high power and energy sources to control its thermal and physical properties. Thus, after conceiving the vast importance of $\mathrm{Mg}_{3} \mathrm{~N}_{2}$ in several industries, authors wish to investigate an approach that could be beneficial to modify the physical and thermal properties of $\mathrm{Mg}_{3} \mathrm{~N}_{2}$ powder.

It is well established that the energy can effectively interact with any matter at a distance and cause action. The energy is exist in various fields such as electric, magnetic etc. Furthermore, researchers have confirmed that biomagnetic fields are present around the human body, which has been evidenced by electromyography (EMG), electrocardiography (ECG) and electroencephalogram (EEG) [8,9]. Moreover, a human has the ability to harness the energy from environment/universe and can transmit it to any object (living or non-living) around the Globe. The object(s) always receive the energy and responded into useful way that is called biofield energy. This process is termed as biofield energy treatment. The National Center for Complementary and Alternative Medicine (NCCAM) considered the biofield treatment (or healing therapy) under subcategory of energy therapies $[10,11]$. Mr. Trivedi's unique biofield energy treatment is known as The Trivedi Effect. Mr. Trivedi's biofield energy treatment is known to alter the physical, structural and atomic characteristic in several metals [12-14] and ceramics $[15,16]$. Our group previously reported that biofield treatment has substantially altered the lattice parameter, crystallite size, and particle size in silicon carbide [17] and manganese oxide [18]. Hence, based on the outstanding results accomplished by biofield energy treatment on metals and ceramics, an attempt was made to evaluate the effect of biofield treatment on thermal and physical properties of $\mathrm{Mg}_{3} \mathrm{~N}_{2}$ powder using differential scanning calorimetry (DSC), thermogravimetric analysis (TGA), and X-ray diffraction (XRD).

*Corresponding author: Snehasis Jana, Trivedi Science Research Laboratory Pvt. Ltd., Hall-A, Chinar Mega Mall, Chinar Fortune City, Hoshangabad Rd., Bhopal-462026, Madhya Pradesh, India, Tel: +91-755-6660006; E-mail: publication@trivedieffect.com

Received September 14, 2015; Accepted October 21, 2015; Published October 23, 2015

Citation: Trivedi MK, Tallapragada RM, Branton A, Trivedi D, Nayak G, et al. (2015) Evaluation of Thermal and Physical Properties of Magnesium Nitride Powder: Impact of Biofield Energy Treatment. Ind Eng Manage 4: 177. doi:10.4172/21690316.1000177

Copyright: (c) 2015 Trivedi MK, et al. This is an open-access article distributed under the terms of the Creative Commons Attribution License, which permits unrestricted use, distribution, and reproduction in any medium, provided the original author and source are credited. 
Citation: Trivedi MK, Tallapragada RM, Branton A, Trivedi D, Nayak G, et al. (2015) Evaluation of Thermal and Physical Properties of Magnesium Nitride Powder: Impact of Biofield Energy Treatment. Ind Eng Manage 4: 177. doi:10.4172/2169-0316.1000177

\section{Methods}

The $\mathrm{Mg}_{3} \mathrm{~N}_{2}$ powder was purchased from Sigma Aldrich, India. The powder was equally divided into two parts, referred as control and treated. The treated group was in sealed pack and handed over to Mr. Trivedi for biofield energy treatment under standard laboratory condition. Mr. Trivedi provided the biofield treatment through his energy transmission process to the treated group without touching the sample. The control and treated samples were characterized using DSC, TGA and XRD.

\section{DSC analysis}

The thermal analysis of $\mathrm{Mg}_{3} \mathrm{~N}_{2}$ powder was performed using DSC. For DSC study, Pyris-6 Perkin Elmer, with a heating rate of $10^{\circ} \mathrm{C} / \mathrm{min}$ under nitrogen atmosphere was used. The specific heat capacity of $\mathrm{Mg}_{3} \mathrm{~N}_{2}$ powder was calculated from the DSC curve.

\section{TGA-DTG analysis}

TGA analysis was carried out using Mettler Toledo TGA-DTG system. The samples were heated from room temperature to $900^{\circ} \mathrm{C}$ with a heating rate of $10^{\circ} \mathrm{C} / \mathrm{min}$. The change in weight of the sample was observed in TGA curve, whereas the DTG curve provided the $\mathrm{T}_{\max }$, where sample lost maximum of its weight.

\section{XRD study}

The XRD analysis of control and treated $\mathrm{Mg}_{3} \mathrm{~N}_{2}$ powder was carried out on Phillips, Holland PW 1710 X-ray diffractometer system. It had a copper anode with nickel filter. The radiation of wavelength used by the XRD system was $1.54056 \AA$. This XRD system provided the data in the form of a chart of $2 \theta v s$. intensity and a detailed table containing peak intensity counts, $d$ value $(\AA)$, peak width $\left(\theta^{\circ}\right)$, relative intensity (\%) etc. Further, the PowderX software was used to calculate lattice parameter and unit cell volume of $\mathrm{Mg}_{3} \mathrm{~N}_{2}$ powder samples. The weight of the unit cell was calculated as, molecular weight multiplied by the number of atoms present in a unit cell. Also, the density of the unit cell was computed as follows:

$$
\text { Density }=\frac{\text { Weight of unit cell }}{\text { Volume of unit cell }}
$$

The crystallite size (G) was calculated by using Scherrer equation as given below:

$$
\text { Crystallite size }(G)=k \lambda /(b \operatorname{Cos} \theta) \text {, }
$$

Here, $\lambda$ is the wavelength of radiation used, $\mathrm{k}$ is the equipment constant (0.94) and b is full width half maximum (FWHM) and, $\theta$ is Bragg's angle.

Besides, the percent change in the unit cell volume was calculated using following equation:

$$
\% \text { change in unit cell volume }=\frac{\left[\mathrm{V}_{\text {Treated }}-\mathrm{V}_{\text {Control }}\right]}{\mathrm{V}_{\text {Control }}} \times 100
$$

Where $\mathrm{V}_{\text {Control }}$ and $\mathrm{V}_{\text {Treated }}$ are the unit cell volume of control and treated samples respectively. Similarly, the percent change in all other parameters such as lattice parameter, density, molecular weight, and crystallite size were calculated.

\section{Results and Discussion}

\section{DSC analysis}

The DSC was employed to study the thermal characteristics of control and treated $\mathrm{Mg}_{3} \mathrm{~N}_{2}$ powders. For DSC analysis, treated part was divided into three parts, considered as T1, T2, and T3. Figures 1a-1d shows the DSC curves of control and treated $\mathrm{Mg}_{3} \mathrm{~N}_{2}$ samples. From the DSC curve, the heat absorbed $(\Delta \mathrm{H})$ during rise in temperature was recorded, which was further used to compute the specific heat capacity of samples. The DSC curve showed a broad peak in control sample, which was started from $285.09^{\circ} \mathrm{C}$ and ended at $363.45^{\circ} \mathrm{C}$. However, treated $\mathrm{T} 1$ sample also exhibited the broad peak, which started from $269.74^{\circ} \mathrm{C}$ and ended at $354.24^{\circ} \mathrm{C}$. Similarly, T2 and T3 showed the onset at $297.88^{\circ} \mathrm{C}$ and $297.57^{\circ} \mathrm{C}$ and endset at $407.80^{\circ} \mathrm{C}$ and $382.42^{\circ} \mathrm{C}$, respectively. In addition, the peak temperature in this process was found to be $342.47^{\circ} \mathrm{C}, 329.84^{\circ} \mathrm{C}, 355.63^{\circ} \mathrm{C}$, and $349.9^{\circ} \mathrm{C}$ in control, $\mathrm{T} 1$, $\mathrm{T} 2$, and T3 respectively. Furthermore, the heat absorbed $(\Delta \mathrm{H})$ by the control samples during temperature rise $\left(285 \rightarrow 363.45^{\circ} \mathrm{C}\right)$ was $175.6 \mathrm{~J} / \mathrm{g}$. However, the heat absorbed by treated samples T1, T2, and T3 were $277.6 \mathrm{~J} / \mathrm{g}\left(299.74 \rightarrow 354.84^{\circ} \mathrm{C}\right), 610.1 \mathrm{~J} / \mathrm{g}\left(297.88 \rightarrow 407.80^{\circ} \mathrm{C}\right)$, and 479.7 $\mathrm{J} / \mathrm{g}\left(297.57 \rightarrow 382.42^{\circ} \mathrm{C}\right)$, respectively (Table 1). It indicated that the $\Delta \mathrm{H}$ was increased by $58.03,247.36$, and $173.3 \%$ in treated T1, T2, and T3, respectively as compared to the control (Figure 2). In addition, the specific heat capacity $\left(C_{p}\right)$ i.e. the heat required to raise the temperature

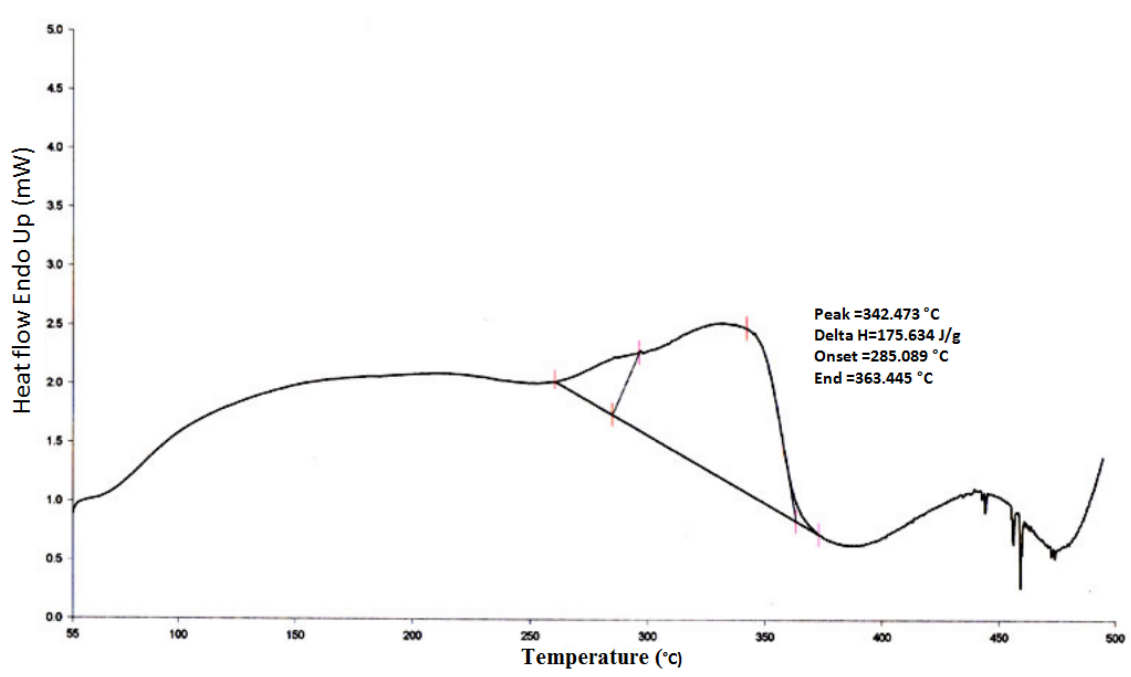

Figure 1a: DSC curve of control magnesium nitride sample. 
Citation: Trivedi MK, Tallapragada RM, Branton A, Trivedi D, Nayak G, et al. (2015) Evaluation of Thermal and Physical Properties of Magnesium Nitride Powder: Impact of Biofield Energy Treatment. Ind Eng Manage 4: 177. doi:10.4172/2169-0316.1000177

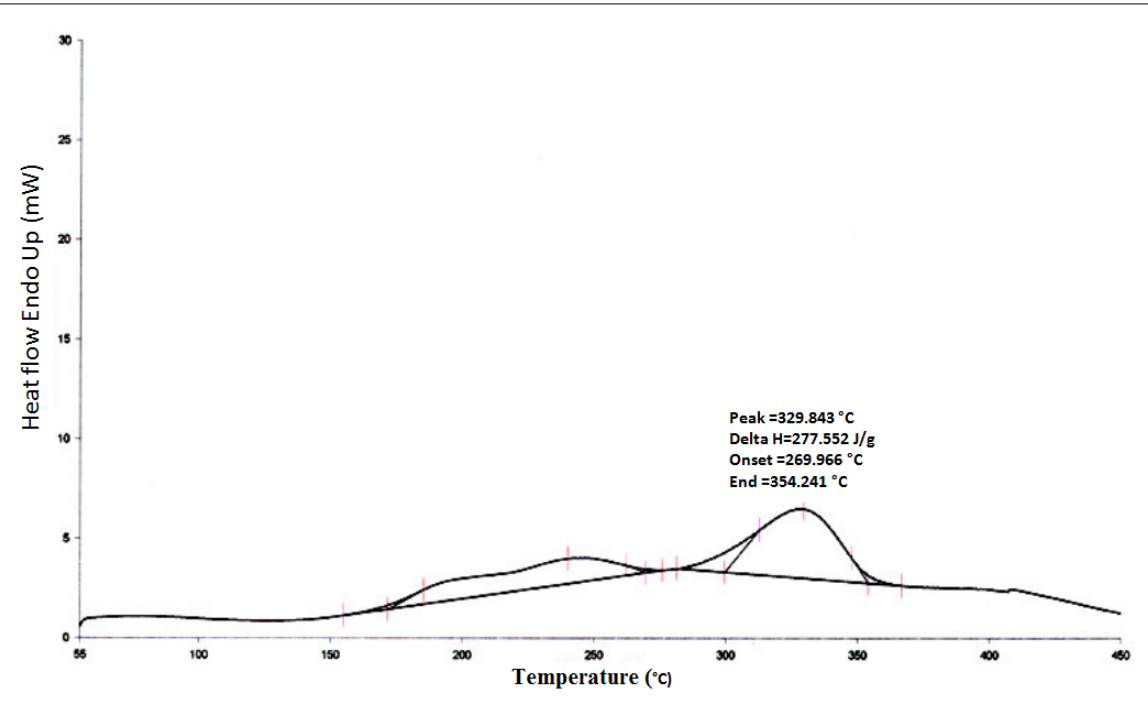

Figure 1b: DSC curve of treated (T1) magnesium nitride sample.

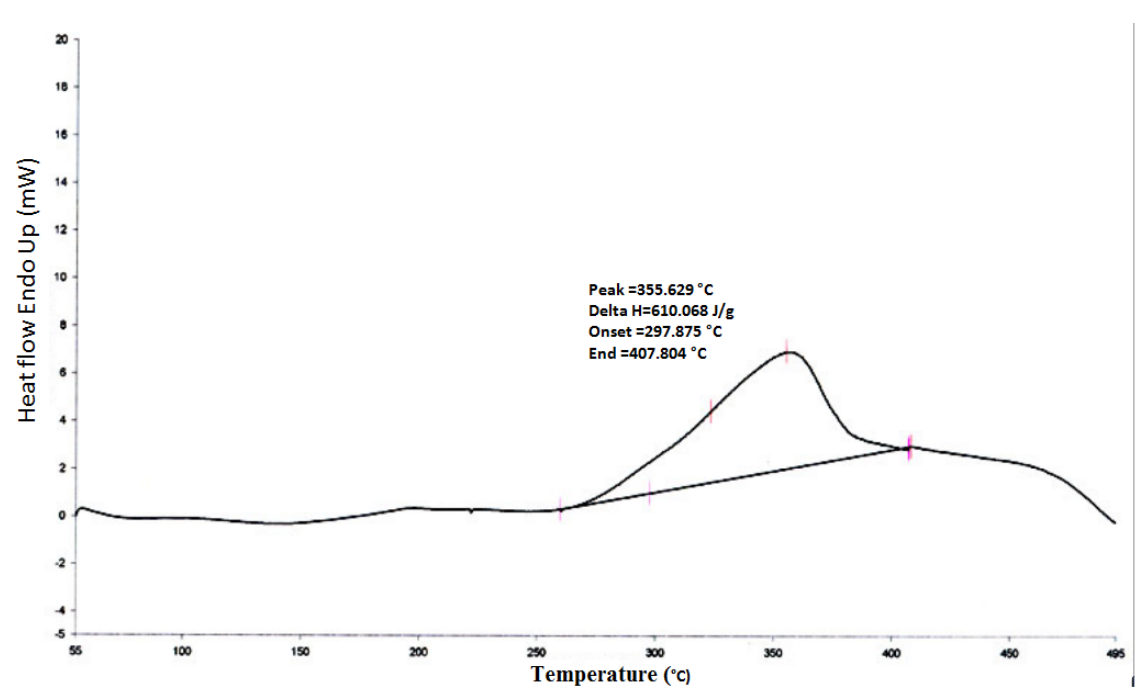

Figure 1c: DSC curve of treated (T2) magnesium nitride sample.

\begin{tabular}{|c|c|c|c|c|c|}
\hline & Onset Temperature $\left({ }^{\circ} \mathrm{C}\right)$ & Peak Temperature $\left({ }^{\circ} \mathrm{C}\right)$ & Endset Temperature $\left({ }^{\circ} \mathrm{C}\right)$ & $\Delta \mathbf{H}(\mathrm{J} / \mathrm{g})$ & Specific heat capacity, $\mathrm{C}_{\mathrm{p}}\left(\mathrm{Jg}^{-10} \mathrm{C}^{-1}\right)$ \\
\hline Control & 285.09 & 342.47 & 363.45 & 175.6 & 2.24 \\
\hline T1 & 269.74 & 329.84 & 354.24 & 277.6 & 5.09 \\
\hline T2 & 297.88 & 355.63 & 407.80 & 610.1 & 5.55 \\
\hline T3 & 297.57 & 349.9 & 382.42 & 479.7 & 5.65 \\
\hline
\end{tabular}

$\mathrm{T}$ : Trearted; $\Delta \mathrm{H}$ : Heat absorbed by sample

Table 1: DSC analysis of magnesium nitride powder.

of one gram substance by one degree Celsius, was $2.24 \mathrm{Jg}^{-10} \mathrm{C}^{-1}$ in the control $\mathrm{Mg}_{3} \mathrm{~N}_{2}$ sample, which was significantly increased to 5.09, 5.55, and $5.65 \mathrm{~J} \mathrm{~g}^{-10} \mathrm{C}^{-1}$ in $\mathrm{T} 1, \mathrm{~T} 2$, and $\mathrm{T} 3$ samples, respectively. It indicated that $C_{p}$ was substantially increased by $127.22,147.63$, and $152.23 \%$ in treated T1, T2, and T3 samples, respectively as compared to the control. Moreover, our group previously reported that biofield treatment had altered the latent heat of fusion in cadmium powder [19]. The specific heat capacity is depended on the number of degrees of freedom. Like the molecule with $\mathrm{n}$ atom have $3 \mathrm{n}$ number of degrees of freedom [20]. Thus, $\mathrm{Mg}_{3} \mathrm{~N}_{2}$ has 15 number of degrees of freedom. Each degree of freedom allows the particle to store thermal energy. In addition, the translation kinetic energy of the particle is one of the possible degrees of freedom, which manifests to the change in temperature [21]. Thus, based on this, it is assumed that biofield treatment possibly altered the energy associated with degrees of freedom other than kinetic energy such as rotational, vibrational etc. This might be the probable reason 
Citation: Trivedi MK, Tallapragada RM, Branton A, Trivedi D, Nayak G, et al. (2015) Evaluation of Thermal and Physical Properties of Magnesium Nitride Powder: Impact of Biofield Energy Treatment. Ind Eng Manage 4: 177. doi:10.4172/2169-0316.1000177

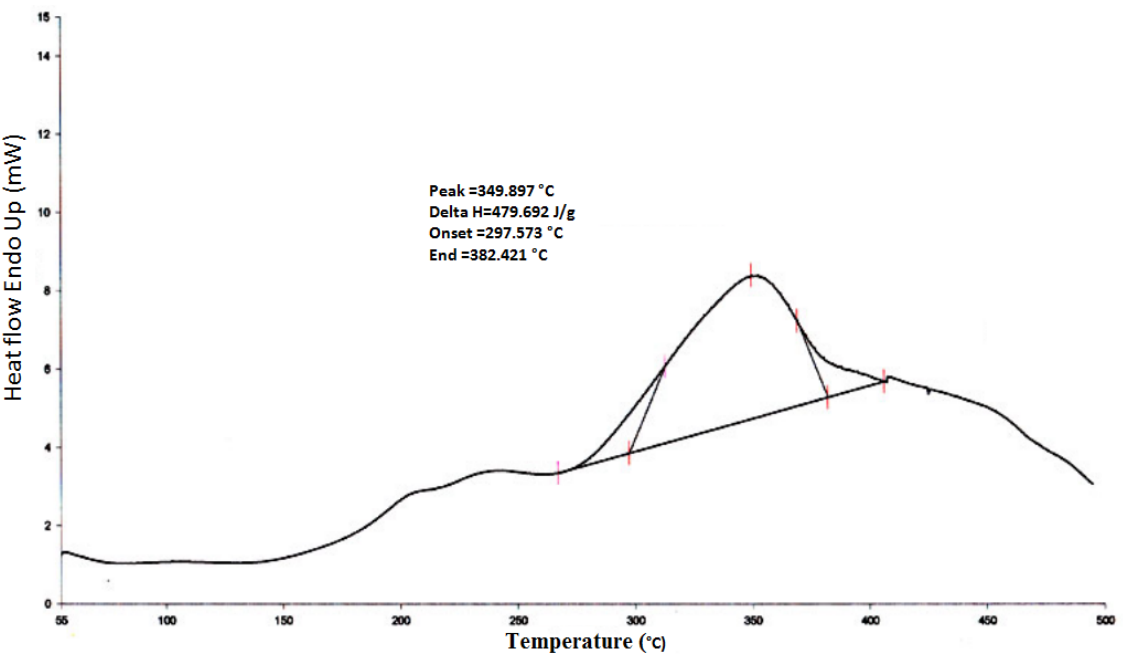

Figure 1d: DSC curve of treated (T3) magnesium nitride sample.

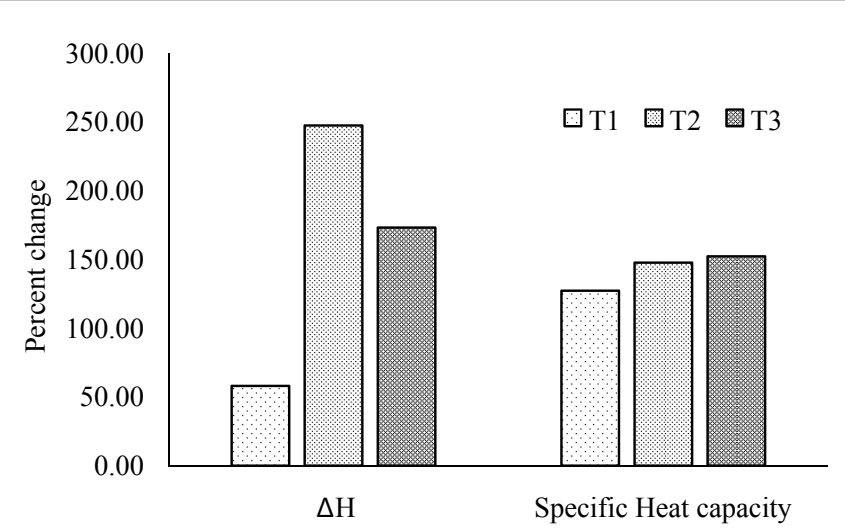

Figure 2: Effect of biofield treatment on thermal properties of magnesium nitride.

for change in specific heat capacity of treated $\mathrm{Mg}_{3} \mathrm{~N}_{2}$ powder.

\section{TGA analysis}

The TGA analysis of $\mathrm{Mg}_{3} \mathrm{~N}_{2}$ powder was carried out in the temperature range $0-900^{\circ} \mathrm{C}$, under nitrogen atmosphere. Figure 3 shows the TGA curve of control and treated $\mathrm{Mg}_{3} \mathrm{~N}_{2}$ samples. The control sample showed that the sample lost $4.10 \%$ of its initial weight till $421^{\circ} \mathrm{C}$, afterward the weight of the sample was continuously increased. It was reported that the reduction in weight loss of $\mathrm{Mg}_{3} \mathrm{~N}_{2}$ in TGA curve in $\mathrm{N}_{2}$ atmosphere under $500^{\circ} \mathrm{C}$ was due to the release of $\mathrm{H}_{2} \mathrm{O}, \mathrm{CO}_{2}, \mathrm{~N}_{2}$ and $\mathrm{O}_{2}$ from the surface of powder [22]. However, the weight of the sample was started to increase after $421^{\circ} \mathrm{C}$. It is reported that during TGA analysis, the presence of water and oxygen oxidises the $\mathrm{Mg}_{3} \mathrm{~N}_{2}$ to $\mathrm{MgO}$ and increase the weight of the sample [23]. The DTG showed the control sample gained its maximum weight at $582.33^{\circ} \mathrm{C}$, possibly due to oxidation of $\mathrm{Mg}_{3} \mathrm{~N}_{2}$. Furthermore, the control sample was continued to gain the weight by $4.25 \%$ till temperature reach to $657.47^{\circ} \mathrm{C}$. However, the treated sample lost its weight of $2.66 \%$ upto $391.33^{\circ} \mathrm{C}$, possibly due to release of $\mathrm{H}_{2} \mathrm{O}, \mathrm{CO}_{2}, \mathrm{~N}_{2}$ and $\mathrm{O}_{2}$ from the surface of powder. After that the treated sample was started to gain the weight at $391.33^{\circ} \mathrm{C}$ that might be due to oxidation of $\mathrm{Mg}_{3} \mathrm{~N}_{2}$. The DTG showed that sample
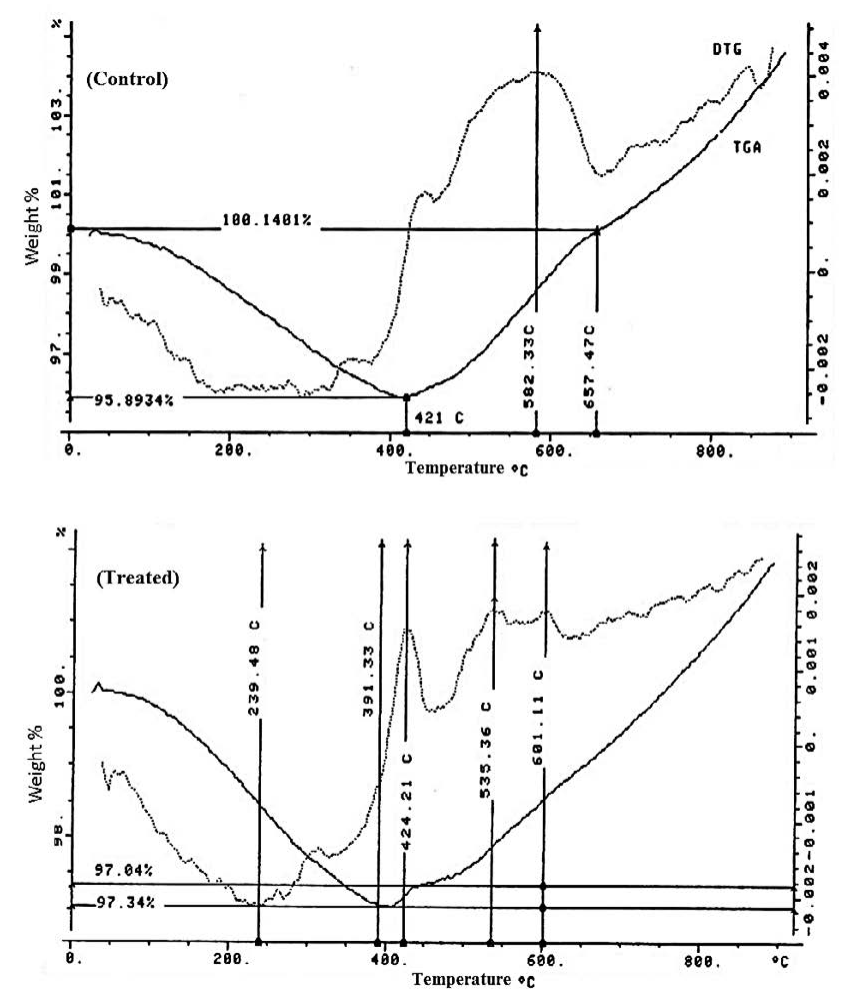

Figure 3: TGA curve of magnesium nitride powder.

showed the three different peaks corresponding to weight gain at i.e. at $424.21^{\circ} \mathrm{C}, 535^{\circ} \mathrm{C}$, and $601.11^{\circ} \mathrm{C}$. Moreover, in order to find out the probable cause for the alteration in thermal properties, the control and treated $\mathrm{Mg}_{3} \mathrm{~N}_{2}$ samples were examined using XRD.

\section{X-ray diffraction (XRD)}

XRD is a non-destructive and quantitative technique, which has been extensively used to determine the crystal structure parameters 

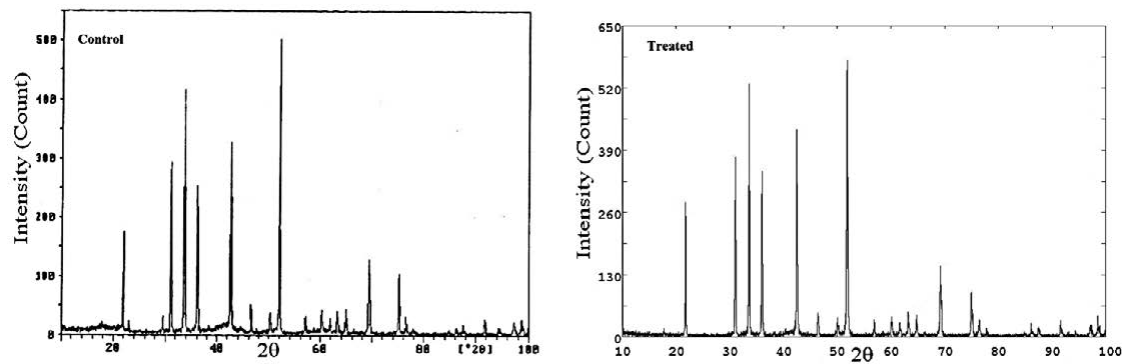

Figure 4: XRD diffractogram of magnesium nitride powder.

\begin{tabular}{|c|c|c|c|c|}
\hline \multirow{2}{*}{$\begin{array}{c}\text { Plane } \\
\text { (hkl) }\end{array}$} & \multicolumn{2}{|c|}{ Control } & \multicolumn{2}{c|}{ Treated } \\
\cline { 2 - 5 } & $\mathbf{2} \boldsymbol{\theta}$ (Degree) & $\begin{array}{c}\text { Relative } \\
\text { Intensity }\end{array}$ & $\mathbf{2} \boldsymbol{\theta}$ (Degree) & $\begin{array}{c}\text { Relative } \\
\text { Intensity }\end{array}$ \\
\hline $\mathbf{2 1 1}$ & 21.89 & 31.7 & 21.80 & 44.6 \\
\hline $\mathbf{2 2 2}$ & 31.10 & 50.4 & 31.03 & 67.8 \\
\hline $\mathbf{3 2 1}$ & 33.67 & 76.5 & 33.58 & 97.4 \\
\hline $\mathbf{4 0 0}$ & 36.05 & 43.9 & 35.97 & 65.7 \\
\hline $\mathbf{3 3 2}$ & 42.57 & 58.7 & 42.47 & 79.6 \\
\hline $\mathbf{5 3 1}$ & 51.91 & 100 & 51.81 & 100 \\
\hline $\mathbf{4 4 0}$ & 52.08 & 41.6 & 51.98 & 51.8 \\
\hline $\mathbf{7 2 1}$ & 69.31 & 27 & 69.21 & 22.5 \\
\hline $\mathbf{7 3 2}$ & 75.05 & 18.4 & 74.97 & 16.8 \\
\hline
\end{tabular}

Table 2: Effect of biofield energy treatment on the Bragg angle $(2 \theta)$ and relative intensities of XRD peaks of magnesium nitride powder.

\begin{tabular}{|l|c|c|c|c|c|}
\hline Group & $\begin{array}{c}\text { Lattice } \\
\text { parameter } \mathbf{( A )}\end{array}$ & $\begin{array}{c}\text { Unit cell } \\
\text { volume } \\
\left(\times \mathbf{1 0}^{-23} \mathbf{c m}^{3}\right)\end{array}$ & $\begin{array}{c}\text { Density } \\
\mathbf{( g / c c )}\end{array}$ & $\begin{array}{c}\text { Molecular } \\
\text { weight } \mathbf{( g /} / \\
\mathbf{m o l})\end{array}$ & $\begin{array}{c}\text { Crystallite } \\
\mathbf{s i z e} \\
\mathbf{( n m})\end{array}$ \\
\hline Control & 9.9551 & 98.6586 & 2.716 & 100.855 & 108.05 \\
\hline Treated & 9.9752 & 99.2586 & 2.699 & 101.469 & 144.04 \\
\hline $\begin{array}{l}\text { Percent } \\
\text { change }\end{array}$ & 0.20 & 0.61 & -0.60 & 0.61 & 33.30 \\
\hline
\end{tabular}

Table 3: Effect of biofield energy treatment on the lattice parameter, unti cell volume, density, molecular weight and crystallite size of magnesium nitride.

such as lattice parameters, unit cell volume etc. The XRD diffractogram of control and treated $\mathrm{Mg}_{3} \mathrm{~N}_{2}$ samples are presented in Figure 4. The control sample showed the crystalline peaks at $2 \theta$ equal to $21.89^{\circ}$, $31.10^{\circ}, 33.67^{\circ}, 36.05^{\circ}, 42.57^{\circ}, 51.91^{\circ}, 52.08^{\circ}, 69.31^{\circ}$, and $75.05^{\circ}$, which were indexed to the crystalline plane (211), (222), (321), (400), (332), (531), (440), (721), and (732) respectively, according to Joint Committee on Powder Diffraction Standards (JCPDS) card No. 350778 [24]. However, treated sample showed crystalline peaks at $21.80^{\circ}$, $31.03^{\circ}, 33.58^{\circ}, 35.97^{\circ}, 42.47^{\circ}, 51.81^{\circ}, 51.98^{\circ}, 69.21^{\circ}$, and $74.97^{\circ}$. This indicated that all peaks in the treated sample were shifted to lower Bragg angle as compared to the control. Also, the peak corresponding to plane (531) was found to be the most intense among other peaks in both control and treated samples. Further, the relative intensities of all peaks in control and treated sample were summarized in Table 2. The data showed that relative intensities of all peaks were significantly altered in the treated sample as compared to the control. Inoue et al. reported that the change in crystal morphology leads to alter the relative intensities of XRD peaks [25]. Also, our group reported that the biofield treatment had altered the particle size, and surface morphology in zinc [10] and antimony powder [11]. Thus, it is possible that the size, shape and surface morphology of treated $\mathrm{Mg}_{3} \mathrm{~N}_{2}$ might alter after biofield treatment and that might be the probable cause for the alteration in relative intensities in treated sample. Furthermore, the crystal structure parameters such as lattice parameter, unit cell volume, density and molecular weight were computed and presented in Table 3. The data exhibited that the lattice parameter of unit cell was increased by $0.20 \%$ in treated sample as compared to the control. Hirai et al. reported that the stress (or pressure) on the compounds causes the alteration in relative intensities and lattice strain [26]. It is also reported that increase in lattice parameter leads to shift the XRD peaks toward lower Bragg angle and vice versa [27]. Hence, the increase in lattice parameter was supported by the shifting of XRD peaks toward lower Bragg's angle in treated $\mathrm{Mg}_{3} \mathrm{~N}_{2}$ sample. Paszkowicz et al. reported that the lattice parameter of $\mathrm{Mg}_{3} \mathrm{~N}_{2}$ was increased by $0.14 \%$, when temperature was raised from $1 \mathrm{~K}$ up to $304.5 \mathrm{~K}$. It is mentioned that the change in lattice parameter caused the alteration in the thermal expansion coefficient of the compound [28]. Thus, it is assumed that the change in lattice parameter i.e. distance between two atoms might be responsible for the alteration in thermal properties. Besides, the increase in lattice parameter led to increase the unit cell volume by $0.61 \%$ in treated sample as compared to the control. In relation to this, the change in lattice parameter is also known as lattice strain $(\varepsilon)$, which is related to stress $(\sigma)$ by following equation [29]:

$$
\sigma=\mathrm{Y} \varepsilon
$$

\section{Where $\mathrm{Y}$ is Young's Modulus}

In above equation, the negative strain indicated the compressive stress, whereas positive strain is related to tensile stress. Thus, the positive lattice strain found in treated $\mathrm{Mg}_{3} \mathrm{~N}_{2}$ sample suggests that biofield treatment might induce tensile stress and that might be the responsible for alteration in lattice parameter and unit cell volume. Besides, the increase in unit cell volume led to reduce the density by $0.60 \%$ in the treated $\mathrm{Mg}_{3} \mathrm{~N}_{2}$ sample as compared to the control. Contrarily, the molecular weight of treated $\mathrm{Mg}_{3} \mathrm{~N}_{2}$ was increased from $100.855 \mathrm{~g} / \mathrm{mol}$ (control) to $101.469 \mathrm{~g} / \mathrm{mol}$. It is already reported that biofield treatment has significantly altered the atomic weight and density in silicon carbide [17]. Furthermore, the crystallite size of control and treated $\mathrm{Mg}_{3} \mathrm{~N}_{2}$ powder were computed using Scherrer equation and calculated result are presented in Table 3 . The crystallite size was increased from $108.05 \mathrm{~nm}$ (control) to $144.04 \mathrm{~nm}$ in treated sample. It suggests that the crystallite size of treated $\mathrm{Mg}_{3} \mathrm{~N}_{2}$ powder was significantly increased by $33.30 \%$ as compared to the control. The increase in crystallite size could be due to the movement of crystallite boundaries in treated sample after biofield treatment. It is possible that the energy, which probably transferred through biofield treatment might induce the movements of dislocation present at crystallite boundaries. 
Citation: Trivedi MK, Tallapragada RM, Branton A, Trivedi D, Nayak G, et al. (2015) Evaluation of Thermal and Physical Properties of Magnesium Nitride Powder: Impact of Biofield Energy Treatment. Ind Eng Manage 4: 177. doi:10.4172/2169-0316.1000177

\section{Conclusions}

In summary, the biofield energy treatment has substantially altered the specific heat capacity, crystallite size, and unit cell parameters. The specific heat capacity of treated $\mathrm{Mg}_{3} \mathrm{~N}_{2}$ was significantly increased up to $152.23 \%$ as compared to the control. The biofield treatment showed the alteration in the lattice parameter $(0.20 \%)$, unit cell volume $(0.61 \%)$, density $(-0.60 \%)$, and molecular weight $(0.61 \%)$ in treated sample as compared to control. On the basis of alteration in relative intensities of XRD peaks in treated sample as compared to control, it is concluded that the biofield energy treatment probably altered the surface morphology of the treated $\mathrm{Mg}_{3} \mathrm{~N}_{2}$ powder. In addition, the crystallite size of the treated sample was significantly increased by $33.30 \%$ as compared to control. Therefore, based on the above outcomes it is concluded that biofield treated $\mathrm{Mg}_{3} \mathrm{~N}_{2}$ could be more useful in chemical and optoelectronic properties.

\section{Acknowledgement}

Authors gratefully acknowledged $\mathrm{Dr}$. Cheng Dong of NLSC from Institute of Physics, and Chinese academy of sciences for providing the facilities to use PowderX software for analyzing XRD data. Authors also would like to thank Trived science, Trivedi master wellness and Trivedi testimonials for their support during the work.

\section{References}

1. Xue CS, Ai YJ, Sun LL (2007) Synthesis and photoluminescence properties of $\mathrm{Mg}_{3} \mathrm{~N}_{2}$ powders. Rare Met Mater Eng 36: 2020-2022.

2. Veitch GE, Bridgwood KL, Rands-Trevor K, Ley SV (2008) Magnesium nitride as a convenient source of ammonia: preparation of pyrroles. Synlett 2008: 2597-2600.

3. Kojima $\mathrm{Y}$, Kawai $\mathrm{Y}$, Ohba $\mathrm{N}$ (2006) Hydrogen storage of metal nitrides by a mechanochemical reaction. J Power Sources 159: 81-87.

4. Nakano S, Ikawa H, Fukunaga O (1993) High pressure reactions and formation mechanism of cubic $\mathrm{BN}$ in the system $\mathrm{BN} \mathrm{Mg} \mathrm{N}_{2}$. Diamond Relat Mater 2: 11681174.

5. Armenta MGM, Reyes-Serrato A, Borja MA (2000) Ab initio determination of the electronic structure of beryllium-, aluminum-, and magnesium-nitrides: A comparative study. Phys Rev B 62: 4890.

6. Murata T, Itatani K, Howell FS, Kishioka A, Kinoshita M (1993) Preparation of magnesium nitride powder by low-pressure chemical vapor deposition. J Am Ceram Soc 76: 2909-2911.

7. Toyoura K, Goto T, Hachiya K, Hagiwara R (2005) Structural and optical properties of magnesium nitride formed by a novel electrochemical process. Electrochim Acta 51: 56-60.

8. Movaffaghi Z, Farsi M (2009) Biofield therapies: Biophysical basis and biological regulations. Complement Ther Clin Pract 15: 35-37.

9. Priyadarsini K, Thangam P, Gunasekaran S (2014) Kirlian images in medical diagnosis: A survey. IJCA Proceedings on International Conference on Simulations in Computing Nexus 3: 5-7.

10. Aldridge D (1991) Spirituality, healing and medicine. Br J Gen Pract 41: 425 427

11. Hok J, Tishelman C, Ploner A, Forss A, Falkenberg T (2008) Mapping patterns of complementary and alternative medicine use in cancer: an explorative crosssectional study of individuals with reported positive "exceptional" experiences. BMC Complement Altern Med 8: 48.

12. Trivedi MK, Tallapragada RM (2008) A transcendental to changing metal powder characteristics. Met Powder Rep 63: 22-28, 31
13. Dhabade VV, Tallapragada RM, Trivedi MK (2009) Effect of external energy on atomic, crystalline and powder characteristics of antimony and bismuth powders. Bull Mater Sci 32: 471-479.

14. Trivedi MK, Tallapragada RM, Branton A, Trivedi D, Nayak G, et al. (2015) Potential impact of biofield treatment on atomic and physical characteristics of magnesium. Vitam Miner 3: 129.

15. Trivedi MK, Nayak G, Patil S, Tallapragada RM, Latiyal O (2015) Studies of the atomic and crystalline characteristics of ceramic oxide nano powders after bio field treatment. Ind Eng Manage 4: 161.

16. Trivedi MK, Nayak G, Patil S, Tallapragada RM, Latiyal O, et al. (2015) Impact of biofield treatment on atomic and structural characteristics of barium titanate powder. Ind Eng Manage 4: 166.

17. Trivedi MK, Nayak G, Tallapragada RM, Patil S, Latiyal O, et al. (2015) Effect of biofield treatment on structural and morphological properties of silicon carbide. J Powder Metall Min 4: 132.

18. Trivedi MK, Nayak G, Patil S, Tallapragada RM, Latiyal O (2015) Evaluation of biofield treatment on physical, atomic and structural characteristics of manganese (II, III) oxide. J Material Sci Eng 4: 177.

19. Trivedi MK, Nayak G, Patil S, Tallapragada RM, Latiyal O, et al. (2015) An evaluation of biofield treatment on thermal, physical and structural properties of cadmium powder. J Thermodyn Catal 6: 147.

20. Curry JA, Webster PJ (1999) Thermodynamics of atmospheres and ocean Academic Press Medical.

21. Wiberg E, Wiberg N (2001) Inorganic chemistry. Academic Press. Science.

22. Zong F, Meng C, Guo Z, Ji F, Xiao H (2010) Synthesis and characterization of magnesium nitride powder formed by $\mathrm{Mg}$ direct reaction with $\mathrm{N}_{2}$. J Alloy Compd 508 172-176.

23. Kim D, Kim T, Park H, Park D (2011) Synthesis of nanocrystalline magnesium nitride $\left(\mathrm{Mg}_{3} \mathrm{~N}_{2}\right)$ powder using thermal plasma Appl Surf Sci 257: 5375-5379.

24. Mei L, Li JT (2009) Combustion synthesis of ultrafine magnesium nitride powder by Ar dilution. Scripta Mater 60: 141-143.

25. Inoue M, Hirasawa I (2013) The relationship between crystal morphology and XRD peak intensity on $\mathrm{CaSO}_{4} \cdot 2 \mathrm{H}_{2} \mathrm{O}$. J Cryst Growth 380: 169-175.

26. Hirai H, Kondo T, Hasegawa M, Yagi T, Sakashita M, et al. (2000) Structura changes of methane hydrate under high pressure at room temperature. High pressure (Science).

27. Mohapatra J (2013) Defect-related blue emission from ultra-fine Zn1-xCdxS quantum dots synthesized by simple beaker chemistry. Int Nano Lett 3:31

28. Paszkowicz W, Knapp M, Domagala JZ, Kamler G, Podsiadlo S (2001) Lowtemperature thermal expansion of $\mathrm{Mg}_{3} \mathrm{~N}_{2}$. J Alloy Compd 328: 272-275.

29. Soboyejo W (2002) Mechanical properties of engineered materials. CRC press. 